\title{
Coronavirus: "un regalo envenenado". Comentario sobre un artículo explicativo de las pandemias del siglo XX
} Coronavirus: "A poisoned gift". Comment about an article explaining 20th-century pandemics

\section{INTRODUCCIÓN}

Frente a la pandemia que estamos sufriendo, disponemos de recomendaciones e información autorizada del Ministerio de Salud de la Nación y demás autoridades, pero pienso que el comentario de un artículo recientemente publicado en Le Monde Diplomatique puede ayudar a los pediatras a comprender mejor el origen de esta epidemia y otras que se han visto en el mundo en los últimos tiempos.

"La explicación de la creciente vulnerabilidad humana frente a las pandemias no hay que buscarla en un animal, sino en una causa más profunda: la destrucción y manipulación acelerada de la naturaleza" (Sonia Shah).

¿Por qué, en el siglo XX, la humanidad ha sufrido (y sigue sufriendo) pandemias o epidemias de enorme extensión causadas por agentes infecciosos que jamás habían sido observados antes? La respuesta a esta pregunta puede encontrarse en un artículo recientemente publicado por Sonia Shah, ${ }^{1}$ quien es periodista, investigadora y autora de libros científicos, de derechos humanos y de política internacional. Merece citarse su libro The Body Hunters: Testing New Drugs on the World's Poorest Patients, premiado y elogiosamente comentado por The New England Journal of Medicine. Las frases entre comillas son copias textuales de su artículo.

En el siglo XX, centenares de microbios patógenos aparecieron o reaparecieron en regiones donde jamás habían sido observados antes, lo que produjo, en ocasiones, epidemias o pandemias devastadoras. "Lejos de culpar al pangolino o a los murciélagos, las causas de estas tendencias debemos encontrarlas en tres fenómenos: la deforestación, la urbanización y la industrialización desenfrenada".

\section{Encuentros cercanos}

Bajo este subtítulo, la autora comienza reconociendo tres grandes grupos de enfermedades. Uno está formado por virus como el de la inmunodeficiencia humana (VIH), el del Ébola, de África Occidental; el zika, del continente americano; el de Nipah, de Malasia y Bangladesh; el de Marburgo, de África Occidental, etc. La mayoría de ellos provienen de animales salvajes. Pero no se trata de que estos animales estén infectados particularmente por gérmenes patógenos. Muy por el contrario, conviven con esos gérmenes desde hace cientos de miles de años; el problema es que la deforestación hace que tengan que reducir su hábitat a los pequeños espacios que les dejan los asentamientos humanos.

Estos encuentros cercanos y repetidos con el hombre hacen que los virus pasen a ellos (a nosotros) en una proporción en la que nunca hubieran tenido acceso antes y, en esta transferencia a los humanos, dejan de ser benignos y se convierten en agentes patógenos mortíferos. Por ejemplo, "el virus de Ébola se originó en zonas de Âfrica Central y Occidental que sufrieron deforestación reciente. Cuando se talaron sus bosques, los murciélagos tuvieron que ir a colgarse de los árboles de nuestros jardines y de nuestras granjas". A partir de allí, es fácil imaginarse las formas en que un humano puede tomar contacto con el virus comiendo, por ejemplo, una fruta lamida por el murciélago portador. Este fenómeno toma el nombre de pasaje de la barrera de especies y, si ocurre con frecuencia, puede permitir el pasaje interespecie de gérmenes que, en animales salvajes, son benignos, pero, en el hombre, mutan y se transforman en patógenos.

Un segundo grupo contiene las enfermedades transmitidas por mosquitos. En este caso, la difusión de "las enfermedades no se debe a la pérdida del hábitat, sino a su transformación". En efecto, la deforestación produce la desaparición de la capa de hojas muertas sobre el suelo y de las raíces de los árboles, lo que deja un suelo despojado y ahora sometido al intenso sol, en el cual se generan charcos favorables a la reproducción de los mosquitos. Según un estudio realizado en doce países, la autora comenta que "los vectores de agentes patógenos humanos son dos veces más numerosos en las zonas deforestadas que en los bosques que permanecieron intactos".

Un tercer grupo es secundario a la modificación de la población de algunas especies. La destrucción de hábitats en América del Norte produjo una reducción de la población de algunos pájaros (que son pobres vectores de virus del Nilo Occidental) y la sobrepoblación relativa de otros (que son excelentes vectores de dicho virus). Esto aumenta la probabilidad de que un mosquito pique primero a un pájaro infectado y luego a un humano. La autora explica que, en el nordeste de Estados Unidos, la deforestación expulsó a animales, como las comadrejas (que contribuían a regular la 
población de garrapatas), y dejó prosperar a los ratones de patas blancas y el ciervo, que eran excelentes portadores de garrapatas, lo cual aumentó la difusión de las enfermedades transmitidas por ácaros, como la enfermedad de Lyme, que apareció por primera vez en los Estados Unidos en 1975, y ahora hay muchos casos publicados.

\section{Consumo de carne}

Los riesgos de aparición de nuevas enfermedades no solo aumentan debido a la pérdida de hábitats, sino a la forma en que esa pérdida es reemplazada. A los fines de criar y alimentar ganado destinado a la faena, el hombre arrasó una superficie equivalente a la del continente africano. En este contexto, muchos animales son vendidos en el mercado de animales vivos, en los que animales de distintas especies que nunca hubieran tomado contacto entre sí conviven de modo íntimo, situación en la cual los virus pasan fácilmente de una especie a otra. "En este tipo de desarrollo, que ya engendró el síndrome respiratorio agudo grave (SRAS por sus siglas en inglés) producido por un coronavirus, quizá, esté el origen del coronavirus que hoy nos asedia".

"Pero mucho más grave es la situación creada por el sistema de cría industrial. Miles de animales amontonados unos sobre otros (feed lots, etc.) esperando el matadero crean condiciones ideales para que los microbios se reproduzcan y se transformen en agentes patógenos mortales. Por ejemplo, el virus de la gripe aviar es albergado por aves acuáticas, pero que produce estragos en criaderos de pollos en cautiverio, porque se vuelve mucho más virulento. Una de sus cepas, el H5N1, es transmisible al hombre y mata a más de la mitad de los individuos afectados. En 2014, en EE. UU., se sacrificaron decenas de millones de aves de corral para frenar la propagación de una de sus cepas".

Las montañas de deyecciones que se producen en los animales amontonados son imposibles de ser absorbidas por la tierra y brindan óptimas condiciones a los microorganismos, como la Escherichia coli que contamina el agua y otros alimentos, ${ }^{2}$ y produce diarrea sanguinolenta, sepsis y síndrome urémico hemolítico, tan prevalente en Argentina. "Noventa mil estadounidenses son anualmente infectados por Escherichia coli".

\section{Raíces de las pandemias}

La mutación de microbios animales a agentes patógenos humanos no es nueva. Tuvo su origen en el período Neolítico, hace unos 10000 años, cuando el hombre comenzó a cultivar plantas y a domesticar animales. "Aquí yace el origen de los regalos envenenados que estos animales nos han obsequiado: el sarampión, la viruela y la tuberculosis se las debemos a las vacas; la tos ferina, a los cerdos, y la gripe, a los patos".

“La expansión colonial europea produjo otro fuerte empuje al proceso", dice la autora. En el Congo Belga, la urbanización y la construcción de vías férreas permitieron al Lentivirus del macaco perfeccionar su adaptación a los humanos y convertirse en el VIH. En Bangladesh, los británicos avanzaron sobre el humedal de los Sundarbans, lo que expuso a sus habitantes a las bacterias acuáticas. Una de ellas se transformó en el Vibrio cholerae, que diezma poblaciones en repetidas epidemias; la última de ellas, en Haití.

\section{Qué hacer}

Las bases conceptuales que la autora propone para reducir los riesgos de estas tendencias son las siguientes:

Permitir que los animales conserven su hábitat $\mathrm{y}$, así, en vez de transmitir los gérmenes a nosotros, que estos permanezcan en los animales de origen.

Investigar en forma continua los medios en los cuales los microbios mutan más fácilmente, "eliminando oportunamente aquellos que muestran veleidades de adaptación humana e interviniendo antes de que se propaguen". Según la autora, por desgracia, el Gobierno de EE. UU. puso fin a programas que estaban investigando cepas potencialmente patógenas similares al coronavirus $\mathrm{y}$, peor aún, plantea reducir en un $53 \%$ su contribución a la Organización Mundial de la Salud (OMS). No hay duda de que la autora hace saber que la política no es ajena a la salud humana, sino que está inextricablemente ligada a ella.

Por último, la autora cita al epidemiólogo Larry Brilliant: "Las emergencias de virus son inevitables; las epidemias no".

Horacio Lejarraga

Universidad de Buenos Aires

http:/ / dx.doi.org/10.5546/ aap.2020.232

Texto completo en inglés:

http:/ / dx.doi.org/10.5546/ aap.2020.eng.232

Cómo citar: Lejarraga H. Coronavirus: "un regalo envenenado". Comentario sobre un artículo explicativo de las pandemias del siglo XX. Arch Argent Pediatr 2020;118(4):232-233.

\section{REFERENCIAS}

1. Shah S. Regalos envenenados. Le Monde Diplomatique. 2020;249:24-35.

2. Caletti MG. Enfermedades transmitidas por alimentos. En Sociedad Argentina de Pediatría. PRONAP. 2020 (2). [En prensa]. 